TITLE:

\title{
Pagodas and Prophets: Contesting Sacred Space and Power among Buddhist Karen in Karen State
}

$\operatorname{AUTHOR}(S)$ :

Hayami, Yoko

CITATION:

Hayami, Yoko. Pagodas and Prophets: Contesting Sacred Space and Power among Buddhist Karen in Karen State. The Journal of Asian Studies 2011, 70(04): 1083-1105

ISSUE DATE:

2011-11

URL:

http://hdl.handle.net/2433/152402

RIGHT:

(C) Cambridge University Press 2011.; 許諾条件により本文は2012-1101に公開. 


\section{Pagodas and Prophets: Contesting Sacred Space and Power among Buddhist Karen in Karen State}

\section{YOKO HAYAMI}

This paper analyzes multi-layered religious practices among local Buddhist Karen on the plains of Karen State in Burma, within the context of the larger socio-political dynamics of Burmese Buddhism. The purpose is threefold: first, to give ethnographic details of the hybrid nature of religious practices among Buddhist Pwo Karen, thereby demonstrating how sacred space and power are contested, despite the strong hand of the state; second, to challenge the assumed equation between non-Buddhist minorities on the one hand, and Buddhists as a lowland majority aligned to the state on the other; and third, to raise an alternative understanding to predominantly state-centered perspectives on Theravada Buddhism. Field-based observations on the young charismatic Phu Taki and his community, as well as on the practice of pagoda worship called Duwae that has hitherto been undocumented are presented. These are examined in relation to the changing religious policies of the regime, especially since the policies of "Myanmafication" of Buddhism by the reformist council began in 1980 .

\section{INTRODUCTION}

T Ount Zwekabin, situated south of the Karen State capital of Paan $^{1}$, is a 1 limestone mass overlooking marshy plains. Atop this landmark is a monastery, one that has been at the center of Karen Buddhist religious literary culture of the region since the mid-nineteenth century. However, since the 1990 s, a Burman $^{2}$ abbot with strong connections with the present regime has been appointed. Monasteries in the region had become incorporated into the centralized and top-down national monastic organization since the Buddhist reform council in 1980 (see below).

On the surrounding plains, among the Karen-speaking population, ${ }^{3}$ we find rich layers of religious and "folk" cultural practices. Especially significant are

\footnotetext{
Yoko Hayami (yhayami@cseas.kyoto-u.ac.jp), Professor, Center for Southeast Asian Studies, Kyoto University. ${ }^{1}$ Karen State was established by the Burmese government in 1952 with Paan as its capital. Paan district has a population of 41,000, consisting of Karen, Burma, Mon, Pao, Indian and Chinese. In the plains the Pwo-Karen Buddhists are dominant, and in the eastern hills, Sgaw-Karen are more numerous.

${ }^{2}$ In this paper, "Myanmar" is used only when referring directly to the regime after 1989 (State Law and Order Restoration Council and after 1997, State Peace and Development Council).

${ }^{3}$ Karen population are varied in language as well as culture, history, religion, political stance and socioeconomic status. This paper focuses primarily on Buddhist East Pwo Karen, a culturally and geographically fairly coherent population.
} 
prophetic movements, some of which date to the mid-nineteenth century. Others are quite recent. Should we dismiss these as remnants and cultural anomalies of a peripheral world forgotten by modernity, or as conscious evasion by a minority population of the central regime's tightening control? These movements coexist with an array of different religious practices, from monastic Buddhism, lay devotion for revered monks, pagoda worship, and various domestic rituals. Does the incorporation of local monasteries into the countrywide and centralized hierarchical Buddhist organization mean that all of these practices are now somehow incorporated? If not, how do they coexist in a shared geo-political space?

Previous scholarship has tended to treat such movements among the Karen as anomaly or mimicry of Buddhist practices at best, and, in any case unauthentic. Karen movements are often perceived by observers as primarily a "hill" minority response to the given socio-political situation. In discussing these movements, Theodore Stern presented the Karen as a deprived hill minority harboring envy and discontent towards the plains civilization, and the movements as demonstrating an "influence of lowland Buddhist ideology upon their own indigenous faith" (Stern 1968,303). I will demonstrate below that the Telakhon and Leke practices which he discusses in this context actually emerged from among plains-dwelling Buddhist Karen who cannot easily be labeled either anti- or pro-state.

Stern set the tone for discussion of religious practices on the peripheries of the Buddhist state which has tended to dwell on three mutually reinforcing dichotomies: 1) belonging to either hill minority or plains majority; 2) being identified as either essentially non-Buddhist (or mimicking Buddhist elements) or Buddhist, either heterodox or orthodox Buddhist; and 3) being positioned vis-à-vis the state as either anti/non-state or state-aligned. By questioning these dichotomies, we are led to larger questions pertinent to understanding Buddhism, state and society.

In his recent treatise on Zomia, the upland massif of mainland Southeast Asia identified as the hill country populated by people who continue to evade and resist the lowland state, James Scott (2009) devotes his final chapter to a discussion of prophets and rebellions. While acknowledging that "valley religions do make it to the hills," when they do, such as in Karen or Shan contexts, he states, "they are likely to take heterodox and charismatic form" (306). Here, the above dichotomies are reiterated. He recognizes that heterodox elements can be found in the lowland fringes too. The difference, however, is that in the latter case, heterodox movements take place "within an agreed cultural matrix," as "in a lovers' quarrel," whereas the hill prophets and rebellious movements are clearly anti-state or state-evading ("techniques to thwart state incorporation"). Scott admits that it is a difference in kind rather than one of degree. However, within the larger scheme of arguing for resistance and state-evasion by hill-dwellers, such discussion might effectively solidify multiple dichotomies in which the lowland state is seen as the center of Buddhist orthodoxy, while 
prophetic movements in the hills are regarded as a kind of mimicry of Buddhism, or its heterodox offspring in resistance to the state.

Mikael Gravers avoids dichotomous views by recognizing how these movements among Karen, whom he recognizes as Buddhist, have connections to Burmese and Mon religious cosmology. Rather than see them as rebellions against the lowland states, his emphasis is on the temporal continuity of Karen movements, which can be seen as operating upon accumulated memory and cosmological models. Therefore, they must be analyzed not only as "reaction, resistance, or defensive action" against modernity and external forces, but as a "genuine project of re-enchantment of the world," in which they also try to correct a skewed universe (Gravers 2001,25). While I concur with Gravers' analyses on the religious/cosmological contents and their cumulative effect on ethnic consciousness, the continued line of these movements must be placed within the changing politico-religious context of the region as a whole and within the wider setting of Burma/Myanmar.

I propose that we consider the hill/non-Buddhist vis-à-vis the plains/Buddhist, not as being delineated as peripheral, heretical or nonconformist outsiders in relation to the center, i.e. the state, but as being continuous and connected with it.

Studies of Theravada Buddhist societies have taken the state-centered perspective where the state relationship with the sangha becomes the basis for orthodoxy and legitimation (Ishii 1986; Tambiah 1976). This has been a productive paradigm in understanding Buddhism from the perspective of institutionalized religion supporting kingship and state-formation. Recently, however, there have been studies which eschew a focus on state centered perspectives, some of which focus on practices in the peripheries (Borchert 2008, Pattana 2005, Hayashi ed. 2009). ${ }^{4}$

In his analysis of Tai (Lue) Buddhism in Sipsongpanna, southwest China, Thomas Borchert invites scholars to "pay attention to how Buddhist institutions shift within the context of modern forms of state power" (2008, 107). He points out that modern forms of Buddhism are constituted within historically contingent moments in which state forms and non-state actors are in negotiation over what is a legitimate national form of Buddhism. As Yukio Hayashi points out, even as the state institutionalizes Buddhism with a strong hand, underneath its canopy, innumerable local practices will coexist (2009, 9-11). In the state-centered framework, the local "syncretic/heterodox" practices are assumed to be stronger when the center and orthodoxy is weakened. Alternately, perspectives that pay attention to local practices would recognize that the very process of institutionalization of Buddhism by the state in order to rationalize and modernize, will always be

\footnotetext{
${ }^{4}$ An empirically rich and substantial volume edited by Yukio Hayashi was published in Japanese, looking at religious practices in the interstices of states and orthodoxies (Hayashi ed. 2009). Fifteen articles discuss various aspects of religious practices in the peripheries of mainland Southeast Asia and Southwest China, twelve of which are on Buddhist practices.
} 
accompanied by lived practices in the margin that might be labeled heterodox from the perspective of orthodoxy as defined by the state center.

The challenge is to examine the varied practices of local Buddhists and to determine the multiple directions in which these practices are defined, delineated or aligned, not always necessarily vis-à-vis the center, and to reconsider the delineation of religious orthodoxy and the too easy exclusion of certain elements as being syncretic, heterodox or non-Buddhist. In the present case, such delineation is no doubt made differently from varied positions: Buddhism as controlled by the regime; the nationally popular saintly monks; the local Karen monastic leaders; the local prophetic movements; and lay practitioners on various levels, and so on. Even as state-centered Buddhism imposes itself from the top down, authority is never unchallenged, as manifest in competition over sacred space and protective power.

Earlier scholarship attempted to explain the coexistence of Buddhism as a world religion with local practices, including spirit worship, as well as esoteric elements in Theravada Buddhist societies by using such concepts as "Great and Little Tradition," or "syncretism." I question the usefulness of the term syncretism on two counts. First, this assumes an unquestionable, centrally defined pure form and orthodoxy against which other practices are heterodox and syncretic. Secondly, it often remains a descriptive term in that it assumes a harmonious coexistence of varied elements, oblivious to the agency and orientation of the practitioners, as if the "borrowing" of elements and influences were automatic. It further neglects to consider the socio-political context and tends to see religious practices in a power vacuum. Some recent discussions on Buddhism have preferred the concept "hybridity" (Goh 2009; Pattana 2005; McMahan 2009)..$^{5}$ The term allows us to question the absolute dominance of power and authority, and acknowledge the "other" can become involved in forms of counter-discursive cultural practices.

In this paper, I propose to discuss various local practices in a peripheral region within the larger institutional and socio-political context of Buddhist Burma/Myanmar, especially the regime’s policy to control Buddhism since 1980, referred to as a "Myanmafication" of Buddhism (Houtman 1999). I will examine a range of existing practices and their evolving processes by questioning who is defining whose religion as what. What we will see is not a "hill minority" response by "non-Buddhist" Karen, nor is it useful to describe their practices as "Buddhist syncretism." Analyzing hybridity allows us to see on-the-ground practices not as heterodox or immediately anti-state resistance, but as ways in which

${ }^{5}$ The term is drawn from the work of Homi Bhabha who conceives of hybridity as germane to relations between colonizers and the colonized, where the colonized imitate cultural and discursive forms of the dominant power, often turning them in subtle ways against it. "Hybridity represents that ambivalent 'turn' of the discriminated subject into the terrifying, exorbitant object of paranoid classification- a disturbing questioning of the images and presences of authority ... so that other 'denied' knowledges enter upon the dominant discourse and estrange the basis of its authority" (1994, 162). 
practitioners cope with the present situation. I will especially focus on contestations over religious space and power among the various religious sects and agents in the region, and examine the constant negotiation that is not resolved by any monolithic central power.

Understanding of the Karen in Burma by outsiders has been severely limited by the sources used, which were primarily missionary and colonial material that date from before the 1960s. The Karen have been known predominantly as elite Christians antagonistic to the state and to hill-dwelling animists. The well-known story goes as follows: Christian missionaries brought literacy and education to the Karen, raising them from an oppressed and uncivilized tribe to civilized status, thereby forming the basis of a Karen national consciousness (Cady 1958). After the Second World War, Karen separatists began to fight for independence and ethnic conflict continues to this day. Such an account has imprinted on us a simplistic understanding of the religio-political and ethnic divide in which "tribal hill" Karen harbor envy towards the lowland civilization; elite and anti-regime Christian Karen are considered as non-Burmese outsiders, whereas the Buddhist Karen are regarded as assimilated lowlanders and therefore rendered invisible (Anderson 1998, 320). As Gravers points out, it is "in the modern politics of ethnic difference and nationalism ... in which Buddhists belong to the Myanmar state and Christians are more or less outside" $(2001,22)$. This view has precluded serious consideration of the Buddhist Karen, who are by far the more numerous, but not deemed to deserve separate scrutiny from the majority of Burmese Buddhists.

A note is due on pagodas in Burma. Pagodas are Buddhist stupas that contain relics of the Buddha. In Burma, pagodas can be found within monastery grounds, but they are more often constructed separate from monasteries. Whereas a monastery is space for monks to live and carry out their practices managed by the sangha, pagodas are for lay believers to participate in lay practices managed by themselves. The successful construction of a pagoda is a mark of great merit, and evidence of power. Building a pagoda also constitutes an act of propagating religion, since a pagoda visualizes Buddhist order and power (Tosa 2000, 129-133). This is why kings and royalty in history as well as eminent monks, prophetic figures as well as top leaders of the regime since the 1990s, have been actively engaged in constructing pagodas, investing resources and manpower in them.

I will begin by introducing the region, and the two longstanding and prominent movements, Leke and Telakhon, against the background of early religious practices. In accordance with local usage, I will refer to these movements as sects (gaing, religious sects both within and outside the monastic tradition). A further understanding of the religious dynamism in the area today must then be traced back to 1980 and the subsequent "Myanmafication" of Buddhism by the regime. I examine the region's religious dynamics today, including the recent Phu Taki movement, against the background of the changing religious policies of the regime. That is, I will attempt to situate the Phu Taki movement in arguments regarding delineation of Buddhist knowledge and practices. Finally, 
I will analyze the dynamics of longstanding pagoda worship called Duwae ${ }^{6}$ among Buddhist Karen in the area referring especially to pagoda construction as epitomizing competition over land and sources of power.

\section{East Pwo Karen Buddhist Culture}

The plains area surrounding Paan (Figure 1), an area that extends south to the Kyaing River, southeast to Kawkareik, east to the Dawna Range, north to Hlaingbwe, and west to the Thanlwin River, is regarded by the Karen-speaking Buddhist population as the homeland of East Pwo Karen Buddhist culture. ${ }^{7}$ Historically this area has been within the orbit of Mon kingdoms, ${ }^{8}$ and widely dispersed archeological remains attest to the long historicity of Mon Buddhist cultural influence. The area has witnessed a constant flow of populations, as well as political-military rules from Mon, Burman and Thai rulers, and more recently, conflict between the Karen National Union (KNU) and the current Myanmar regime.

Legend recounts that Buddhism was brought to the Karen-speaking population in the region in the late eighteenth to early nineteenth century. In the midnineteenth century, Karen-language Buddhist literature flourished, centered on the Upper Yedagone Monastery atop Mount Zwekabin. The monasteries in the surrounding plains contain numerous palm-leaf manuscripts from this period (Womack 2005,148). The oldest Buddhist Pwo Karen script found so far is a document from Upper Yedagone Monastery dated 1851 (ibid., 127-8).

This region (formerly Tenasserim) had come under British administration following the first Anglo-Burmese War (1824-6). By the second war (1852-3), there was a large influx of population from Upper Burma and British India. ${ }^{9}$

Under British administration, numerous Buddhist sects emerged in Lower Burma as the relations between the Buddhist sangha, state and society were undergoing total reconfiguration (Mendelson 1975,102-111; Tin Maung Maung Than 1993). Meanwhile, anti-colonial rebellions erupted, by leaders who mobilized the masses with claims of supernatural power (Mendelson 1975, 175-9; 1961a; 1961b; Gravers 2001,4-5). In the present Paan vicinities too, during this period of flux, numerous prophetic movements were reported by administrators and missionaries among the Karen in the same region. ${ }^{10}$ The

\footnotetext{
${ }^{6}$ Research was conducted in March and September 2005, February and April of 2006 and 2007, for several days each time.

${ }^{7}$ West Pwo Karen refers to Karen in the Irrawaddy Delta west of Yangon.

${ }^{8}$ According to local legend, the eleventh century Mon Buddhist King Manuha of Thaton visited the area on the west side of Zwekabin. A hunter presented him with some deer meat. The King allowed this man to rule the area, and locals today refer to him as their Karen King.

${ }^{9}$ The population of Tenasserim grew from 70,000 in 1826 to 257,404 in 1872 (South 2003, 90 (original source: Census report of British Burma, 1872 and 1875)).

${ }^{10}$ For comprehensive coverage of cults from the eighteenth century in which Karen were involved, see Gravers (2001) and Stern (1968).
} 


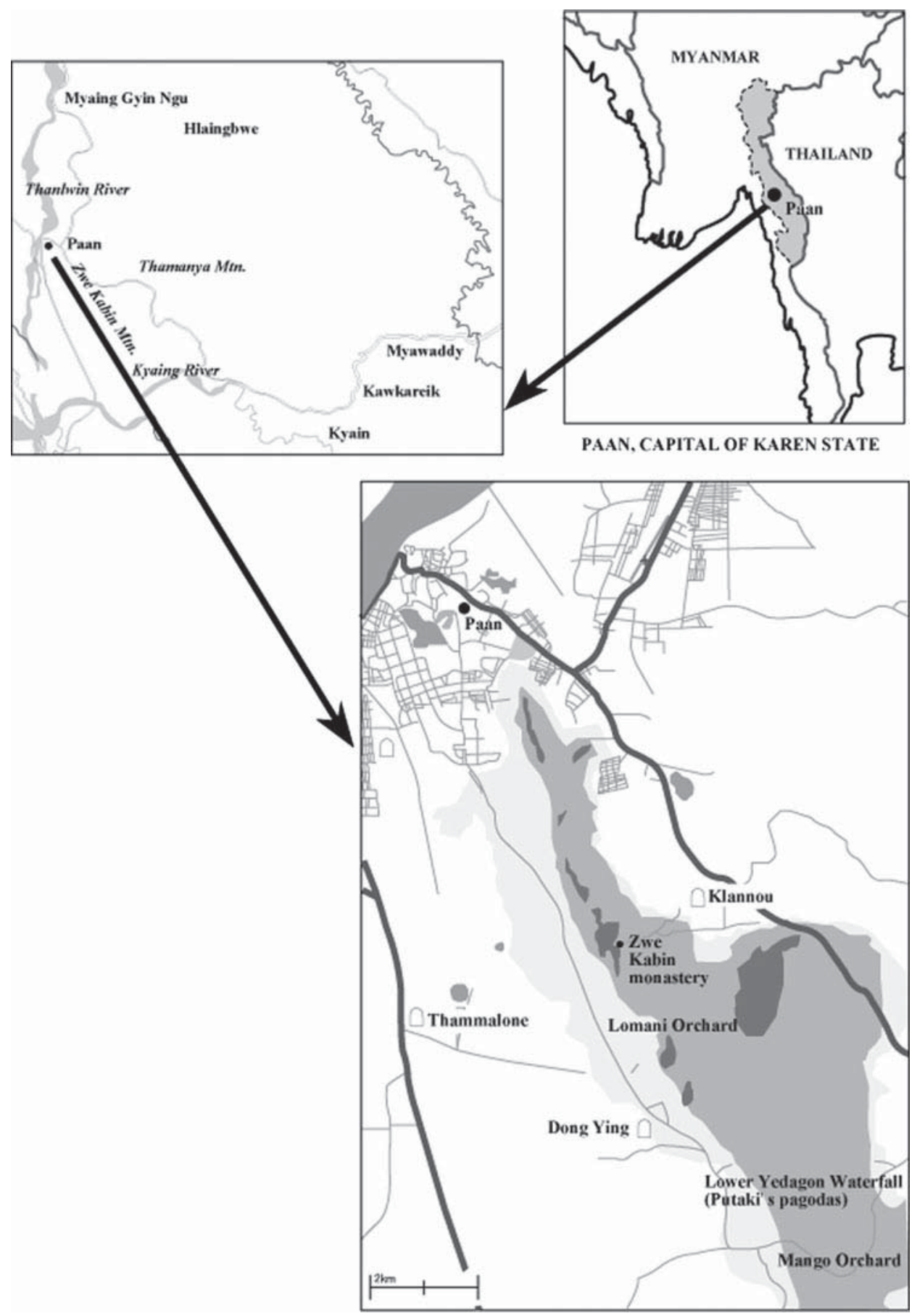

Figure 1. Map of the area surrounding Mount Zwe Kabin in Karen State (with locations of Duwne pagodas at Dong Ying, Thammalone, and Klannou).

leaders of such movements were ascetics, some claiming supernatural power, others calling upon followers to lead a moral life, to abstain from raising livestock and/or to practice vegetarianism while awaiting the coming of Ariya Metteya, the 
future Buddha. Reference to Metteya can be found in similar movements among the Karen in earlier records by missionaries from the 1830s. Some were messianic, and a few fought against the British administration (Stern 1968). Leke and Telakhon were two such sects, both founded in the 1860s, and both have continued to this day. Historical artifacts from these two sects are today displayed in the Karen State Museum in Paan, indicating that they are recognized in local official culture, as well as among the people, as a significant elements of local Karen culture today.

Telakhon (or Telaku in Sgaw) was founded in Kyaing, south of Paan, in the 1860s, and has continued to this day on both sides of the border. ${ }^{11}$ The founder was associated with Phu Ta Maik, the legendary founding monk of Karen Buddhism. Phu Chaik, the leader of Telakhon, was an ascetic in white robes, and followers wore Karen clothing. Men wore their hair in topknots, and were taught to lead a peaceful and harmonious life according to Karen custom, abstaining from rearing livestock, and awaiting the coming of Ariya Metteya, whose arrival would also usher in the Karen kingdom. Telakhon practice mixed elements of spirit worship, Metteya worship, and Karen custom, the central event being a festival performed around a pagoda. The practices of the sect were also related to daily customs and morals in the domestic realm (Man Thint Naung 2006b, 23-7). ${ }^{12}$ Telakhon followers were regarded as Buddhist, and monks were invited to their festivals, although the Phu Caik was seated on an elevated floor, higher than the monks were.

A century after it was founded, there were more than ten thousand followers among its numerous branches in the region on both sides of the border (Tadaw 1959). In the 1960s, at a time when the KNU's military activities moved from central Burma to this border region, bringing military confrontations to the area, expectations for the prophesied redemption heightened to a peak and the number of followers increased from three to ten thousand (Stern 1968). However, divisions emerged, the prophecy was unfulfilled, and in 1967, many followers were killed by the Burmese military for joining the KNLA (Karen National Liberation Army, the military wing of the KNU). In 1972, by contrast, the Phu Chaik was executed by the KNU for challenging its leadership. Following these failures in military and political contexts, Telakhon has continued mainly on the Thai side of the border today (Kwanchewan 2007).

Leke was founded in the 1860s on the west bank of the Thanlwin River. An elderly couple was given a document written in the Leke script, which is said to have originated from two hermits fasting atop Zwekabin in the 1840s. Followers

\footnotetext{
${ }^{11}$ An interview was conducted with the family of a former Telakhon bu kho (priest) in Paan. For details of Telakhon see also Stern and Dodge (n.d.), Stern (1967), Gravers (2001), and Kwanchewan (2007).

${ }^{12}$ According to the Telakhon rule book written in Burmese in 1954, there were fifteen precepts that include the five Buddhist precepts but also eight have to do with morals related to respectful conduct towards parents and marital relationships. The precepts were recited at weddings.
} 
believe that if they maintained moral practices by following the precepts of the dhamma and remained respectful to their parents, Ariya Metteya would arrive in a golden boat. Today, Leke claims to be distinct from Buddhism, eschewing the veneration of the sangha's monks (Leke lay believers can visit monasteries, but the teachers cannot), constructing their own distinctive pagodas, emphasizing vegetarianism, holding Saturday services with music attractive to younger followers, and maintaining their own script and scripture, Karen customs and tradition. The leaders practice vegetarianism, wear topknots and white robes, while lay believers wear Karen clothing at services. At present, Leke is still strong, counting about two hundred teachers and more than sixty places of worship distributed widely over the Karen State, to the eastern mountains and over the border into Thai territory in the refugee camps.

Onlookers' views regarding these longstanding sects have oscillated in time and from one person to another. The local learned Karen monk, U Zagara, while admitting that Telakhon was well within the orbit of Buddhist practice, said Leke "started off as Buddhist but had taken a different path with its emphasis on its own scriptures." Over the century and a half since their emergence, the religious as well as socio-political status of these sects has never been static.

\section{“Myanmafication” in the East Pwo Karen Region}

In 1980, Ne Win's regime held the Buddhist reform council ("the Congregation of the Sangha of All Orders for Purification, Perpetuation and Propagation of the Sasana"). Through these reforms, including policies pertaining to the monastic organization, the regime began to impose its control over Buddhism in the name of purification and protection. Nine Buddhist sects were officially approved, and registration of monks was enforced in order to control politically dangerous monks who threatened the regime. At the same time, the regime re-organized the sangha by instituting the State Sangha Nayaka Council, the organization of monastic councils, which operated at the state/divisional, township, city, and village levels, thereby "streamlining the sangha into the state machinery" (Matthews 1993,416). Since 1988 when Newin stepped down, state patronage of Buddhism moved towards re-centralizing the importance of the sangha, while at the same time tightening its control especially after the student protests of 1988 and the 1990 monastic boycott of the regime in the northern city of Mandalay. In 1991, twenty new monastic titles were instituted and conferred with quadrupled stipends for those monks who demonstrated congenial compliance with the regime, while "bogus" monks were disrobed (Kojima 2009,108). The regime leaders carried out public merit-making at national monuments and local pagodas, mobilizing people to donate for and participate in statesponsored rituals (Schober 1997). 
The East Pwo Karen Buddhist world also met various attempts to absorb them into the regime's newly re-institutionalized Buddhism. From the 1960s, the region had been politically and militarily in a condition of turmoil. Because of continued confrontations between the KNU and the military, the area was designated as a "brown zone" (a contested zone between the military and its enemies). After explicit military conflict ceased in 1988, state-implemented religious policies began to take effect. Monasteries that had been at the center of vernacular Karen culture now became incorporated in the national monastic organization under control by the regime, and monks close to the regime were appointed to some of the important local monasteries. Most symbolic was the appointment of a Burman abbot at the monastery atop Mount Zwekabin, the venue that claimed to be the founding place of local Karen Buddhist literary culture. The abbot held good relationships with the military regime leaders. As the head of the local township Nayaka Council, and with support from the regime, the abbot conducts public works such as the construction of pagodas, clinics, schools and monasteries. He has accomplished various construction works of Buddhist architecture in the region since his appointment in 1995, when he took over from his uncle. These include the (re)construction of the Upper Yedagone Monastery atop Mount Zwekabin, the road leading up to it, the park-like expanse on the southwestern foot of Zwekabin (Lomani Orchard), with one thousand Buddha statues and one hundred and eight pagodas. Furthermore, since 2004, another expanse south of the former has been designated for construction of a similar ground (Mango Orchard) for one thousand Buddha statues, effectively preventing surrounding villagers from squatting on the designated land. The arrival of monks endorsed by the regime at Zwekabin has thus incorporated this once traditional Karen Buddhist realm into the designs of the state-controlled central religious authorities, the landscape now being scattered with sites demonstrating their presence and power. At the same time, some locally revered Karen monks of the Pwo Buddhist literary tradition have been awarded titles by the central sangha. For example, U Zagara, a local intellectual monk who has authored books on Karen religion and culture, and who is abbot of the local Karen monastery in Dong Ying, was awarded such a title (Agga Maha Saddammajotika Sayadaw) in 2004. Thus, Pwo Karen Buddhism in the region has inevitably evolved under the regime and its state-regulated Buddhism.

While "Myanmafication" of local Karen Buddhism was taking place, on the other hand, a saintly monk who maintained his distance from the regime gained the devotion of the masses. In 1981, U Vinaya, a local Pao monk who had begun meditation and severe Buddhist ascetic practices on Thamanya Mountain to the southeast of Paan, had become eminently known as Thamanya Sayadaw, and from the mid-1980s, Pao and Karen followers seeking protection under his power began to form vegetarian communities at the foot of the mountain (Tosa 2009; Rozenberg 2010, 15). Thamanya Sayadaw maintained political 
neutrality and gained further nation-wide reputation after a well-known visit from Daw Aung San Suu Kyi in 1995.

A local Karen village headman from Paan district recounted, "Once when I visited Thamanya to make merit in the name of my village, I was working in the kitchen and realized there was not enough rice for the day. I went to the Sayadaw and he told me to search more. I went back and found that an empty rice basket had been filled. It was a variety only found in Kayah State, but there were no traces that the rice had been carried in. No one knew how it appeared." Such attributions of supernatural power to Thamanya Sayadaw were prevalent among local lay villagers (see also Tosa 2009; and Rozenberg 2010, 94).

In the early 1990s, U Thuzana, a Sgaw Karen disciple of Thamanya Sayadaw began building pagodas in the border hills controlled by the KNU. His motivation was to build a zone consisting of a peaceful field of merit and he prophesied that peace would reign after the construction of fifty white pagodas. His followers believed in his supernatural power, drank water he had sacralized and practiced vegetarianism and meditation at Myaing Gyi Ngu Monastery, northwest of Paan (Gravers 2001). While the leadership of the KNU is primarily Christian, the majority of the soldiers are Buddhist Karen, many of whom followed U Thuzana and split off from the KNU to form the Democratic Karen Buddhist Army (DKBA) in 1994 (Rozenberg 2010,136). During its peak period, DKBA gained the backing of the regime. Unlike Thamanya Sayadaw, who has formed a politically neutral sacred space around Thamanya Mountain, U Thuzana's act of building pagodas, even though he himself intended to remain outside politics (ibid.), became the basis of a political and military faction aligned with the regime.

In the midst of this, another local religious figure emerged from outside the monastic tradition. Phu Taki is a young Pwo Karen charismatic religious leader born in Hlaingkaba on the east side of Zwekabin, who has gathered followers since the 1990s. His community is referred to as a gaing, as with Telakhon and Leke. During his high school years in Dong Ying, he "found himself to be so different from other students"13 that he left school at seventeen and became a samanera (novice) spending three years, three months and three days meditating. However, because he grew his hair, he was expelled from the monastery. He began to call himself Phu Taki, a name he claims he was given in one of his former lives as a Karen. He has twelve costumes, which represent some of his former existences, such as a Karen King of Dong Ying, or a brahmin. His followers wear their hair in top-knots, his ascetic followers wear white robes, while lay followers wear the traditional Karen clothing. He asserts that the core of his doctrine and practice is Buddhist on the one hand and Karen

\footnotetext{
${ }^{13}$ Autobiographical notes derive from two interviews with Phu Taki.
} 


\section{Yoko Hayami}

custom on the other, the primary purpose being to gain protection, and to await the coming of the future Buddha, subsequently to attain nibbana. He endorses local Karen practices such as Duwae wedding vows (see below) and the household ancestral spirit ritual (aung xae). Laying emphasis on vegetarianism, he does not eat solid food and claims transcendental knowledge gained through asceticism and meditation.

Since the mid-1990s, Phu Taki built two hundred pagodas beside the Lower Yedagone Monastery on the western foothills of Zwekabin near Dong Ying, almost adjacent to Lomani Orchard, the above-mentioned park constructed by the regime-endorsed Upper Yedagone abbot. During their first decade of pagoda-building, Phu Taki's community was the butt of much criticism and hostility from the local authorities as well as some lay villagers. In 1998, he moved his community to the present site in Kyaing, allegedly on the advice and endorsement of the revered Thamanya Sayadaw. Phu Taki also claims to have been a disciple of Alantaya Sayadaw, another vegetarian monk, from the region, who was revered nationwide. His position among local Buddhists oscillates and differs from one interview to another. While his followers claim to be Buddhist, a local Karen monk explained: "It is primarily an anachronistic movement centered on Karen customs, only illiterate Karen participate. It isn't really Buddhist but because of pressure from the religious authorities, he has begun to connect himself to become Buddhist."

Phu Taki himself claims to be none but Buddhist, seeking legitimation not from the Nayaka Council but from Thamanya Sayadaw, the revered ascetic monk. However, he claims, "Buddhism is not enough. We need to keep our Karen custom." According to his own count, Phu Taki has around four thousand followers, and a core community of two hundred households. The community is situated on a roaming barren and dry hill, interspersed with pagodas and other constructions of various figures from Karen legends, constituting a panoramic visualized representation of his worldview, much like the enterprises of revered or other prophetic leaders of Burmese sects, demonstrating the intention to build the land of Buddha in this world.

There seem to be important commonalities here with preceding sects and movements: communal moral life in expectation of the arrival of Ariya Metteya and the Karen kingdom, the building of pagodas, maintaining a vegetarian and moral life, as well as emphasis on Karen customs. ${ }^{14}$ While there is influence from Buddhist cosmologies, there are also specific practices and legends drawn from Karen cultural tradition. Phu Taki is definitely among a "dynastic line" of leaders from a series of Karen movements. The accumulated memory in this series of movements across time itself becomes a basis for legitimacy of

\footnotetext{
${ }^{14}$ Vegetarianism among Karen can be understood from the context of Karen practices as a conscious denial of their customary rituals (Hayami 2004), as well as from the Buddhist context where vegetarianism is a mark of asceticism.
} 
newly arising movements, in which Karen cultural elements and strict moral precepts are repeated towards affirming a redefinition of the social order, peace and morality (Gravers 2001). Rootedness in local Karen traditions is definitely a crucial factor.

Turning to the politico-religious context, Phu Takiss pagoda construction took place in parallel with the regime's Myanmafication of Buddhism around Paan. In the midst of this, he made himself the object of donations rather than making donations himself to the sangha. He has acted as the future king and even as a future Buddha, actions which definitely antagonized both the religious and secular authorities as well as some local Karen, both laypeople and monks. However, because he is outside the sangha, he is beyond the control of the Nayaka Council. He claims to be a disciple of the nationally revered yet politically neutral monks Alantaya and Thamanya Sayadaw, and by doing so, consciously engages in efforts to gain Buddhist legitimacy, but not that of the regime and the Nayaka Council. Whether it was intended or not, his practices, especially pagoda-construction, constituted a reaction to the religious politics of the times.

\section{Delineating ORTHODOXY}

Turning attention from the specific region to the wider world of Buddhism in Burma before the 1980 sangha reforms, "two deviant strands" among lay Buddhists in Burma had become prominent: the esoteric practices in the form of mystical sects (gaings) on the one hand; and the popularity of lay meditation practices on the other (Tin Maung Maung Than 1993,18). Both were attracting clientele from important sectors of urban society. Meditation practices constituted the "development of a new institutional space within the overall sacred geography of Burmese Buddhism" (Jordt 2007,43). As for the mystical sects (gaings) dealing with knowledge in the esoteric realm, such as alchemy, astrology, magic and herbal medicine, leaders claimed supernatural power attracting some prominent figures as followers. Alarmed by the popularity of some of these leaders as well as some politically inclined monks, the reforms since the 1980 council were efforts to institute tighter state control of the monastic order and religious practices. Despite such control, interest among laypeople in other ways of approaching religious power had increased.

Keiko Tosa describes the historical process of delineation and exclusion that has occurred through the cultivation of secular knowledge characteristic of esoteric pursuits (lawki pinnya), a process that has consciously separated this trajectory from the orthodox sangha and its sacred Buddhist knowledge (lawkoktara pinnya). This process has progressed gradually since Bodawpaya's reign and through the institutionalization of religion by the state since the late eighteenth century (Tosa 2000). Since then, Buddhist knowledge has been progressively rationalized and defined as knowledge related to the attainment of nibbana, 
while secular arts and practices were excluded by this delineation as something orthodox Buddhist practices should not be involved in.

This trend was emphasized with a new force in the state institutionalization of Buddhism since 1980. A year before the 1980 reform council, the regime had illegalized the rising Shwei Yin Kyaw Gaing, a popular esoteric sect, and arrested its leader, who had gained a large following including politicians and merchants. Numerous eminent monks involved in similar sects adopting elements of secular knowledge and meditative practices, as well as mystical and Mahayanist elements of Buddhism, have been disrobed after $1980 .{ }^{15}$ Explicit efforts have been made to separate the secular knowledge of arts such as alchemy and magic from the sangha. However, rather than leading to the demise of such knowledge and practices, such delineation of sacred/secular realms of knowledge has paradoxically resulted in mystical secular practices and beliefs penetrating more deeply into the lives of lay Buddhists (Tosa 2000, 262-4).

Scholars observing Burmese Buddhism from on-the-ground practices have recognized that the esoteric realm including the gaings constitute a third and inseparable element in Burmese religion along with spirit beliefs and Buddhism (Mendelson 1961a, 230), or even as a domain of Burmese Buddhism itself (Schober 1988). They question the emphasis on "pure Buddhism" and the concept of orthodoxy in Buddhism. ${ }^{16}$ Such scholarly views notwithstanding, the ruling regime has since 1980, institutionalized the centralized monastic organization as the defining body of orthodoxy, and legitimate agency for "purification." In the perspective of this orthodoxy, the esoteric realm is delineated outside of Buddhism.

The religious movements under discussion here among the Karen such as the emergence of Phu Taki, the recent resurgence of Leke, and even the charismatic power of the now deceased Thamanya Sayadaw, can all be conceptually placed on either side of such delineation. Yet from the perspective of local practitioners, orthodoxy has little significance when it comes to how they decide who it is that they will follow, and in whose power they seek refuge and protection. Tosa states that from the point of view of the lay grassroots devotees who revere Thamanya Sayadaw, whether his power derives from Buddhist knowledge and practice or is based on knowledge and practice defined outside of the Buddhist orthodoxy, actually makes little difference $(2009,241)$. Negotiation regarding Duwae practices between Buddhist and other elements discussed below could also be understood as processes of multiple counter-delineation of knowledge and practices.

\footnotetext{
${ }^{15}$ This does not mean that the regime denies such knowledge. Knowledge such as astrology is made full use of in making state-level decisions.

${ }^{16}$ Rozenberg also mentions, that the absolute delineation of orthodoxy and heterodoxy is done on a fallacious premise, and that conceptions of orthodoxy and heterodoxy are structurally deployed and construed $(2010,66)$.
} 


\section{Duwae Pagoda Worship}

Duwae is a widely observed practice among the Buddhist Pwo Karen in the region today. It is often listed together with Telakhon and Leke as a local religious cultural element, and originates from around the same period or possibly earlier than these two sects. However, Duwae is not a gaing (sect). Practitioners refer to Duwae practices as yoya (custom). Yet once we begin to investigate the origins, practices and discourse pertaining to Duwae, we find kaleidoscopic configurations of monastic Buddhism, Ariya Metteya beliefs, Karen customs, as well as spirit worship, depending on the period and speaker/ beholder.

\section{Origin and organization}

According to records kept by local Karen monks and folklorists, the original foundation of Duwae took place at the present Dong Ying Duwae Pagoda ${ }^{17}$ some time before or after the turn of the nineteenth century. The legendary founder, Shin Duwon, returned to this area from a stint as a samanera in Ava (Man Ne San 2005, 52; Man Thint Naung 2006a; 2006b). ${ }^{18}$ In one legend, he lived in a graveyard (an act often associated with esoteric power), and every morning walked for alms. At the time, peasants in the area performed sacrificial rituals for the spirit of a large bodhi tree, offering livestock and liquor. Duwon taught them to lead a vegetarian life, and helped them in daily life, especially by curing illness. Villagers built a residence for him, and "his presence brought prosperity to the village" (Man Ne San 2005, 53). He expelled evil spirits by chanting sutras, cut down the bodhi tree, and built a pagoda in its place, consecrating sutra texts and his own walking stick (Man Thint Naung 2006b, 28-34). Duwon is said to have founded similar pagodas in Kyain-Longkaing south of Kawkareik, and in Klannou east of Zwekabin (ibid., 54-97). Duwon told the villagers to worship the pagoda and then the spirits, to which they can make non-alcohol vegetarian offerings. Man Ne San cites U Santana, a knowledgeable local Karen monk, as remarking that Duwon was revered as a minlaung (future king) or in some cases Ariya with supernatural powers that could control the spirits (Man Ne San 2005, 97-99). Once Duwon departed, villagers elected priests (called kalonkoh) to continue the practice. Duwae thus originated as a way of liberating the locals from evil spirits by introducing pagoda worship and Buddhist practices.

In older sources, Duwae was often referred to together with Telakhon and Leke (Stern and Dodge n.d., 14) as a belief in the coming Buddha Ariya,

\footnotetext{
${ }^{17}$ The Pagoda itself is located in Tao-pon Village but is called Dong Ying Pagoda. Three villages to the southwest of Mount Zwekabin, Tao-pon, Kothaun, and Dong Ying are together referred to locally as Dong Ying.

${ }^{18}$ The most detailed description was written by a local Karen monk U Santana (Man Ne San 2005). Man Thint Naung revised this into a few books. He proposes 1788 as the year of Duwon's return (2006a, 54), and others 1830 (U Kunnawuntha, or Kauhlaing Sayadaw cited in Man Ne San 2005).
} 


\section{Yoko Hayami}

where practitioners wore white robes and made offerings at pagodas seeking salvation, and had been in close association with Telakhon (Stern 1968, 320). ${ }^{19} \mathrm{Up}$ until the 1970s, it was widely believed to be some form of spirit-worship. A local intellectual later wrote that many people "misunderstood that the Duwae pagodas were places where people worshipped the spirits of Duwae" (Man Ne San 2005,103-108). Even among some current practitioners, the Duwae priest is referred to as a nat saya (spirit doctor). According to an older koupaka (pagoda committee) member today, "the first priest of Dong Ying Pagoda, Phu Sein Yae, was a nat saya. Some people called him nat kadaw (spirit medium), but we don't call him that since we are now Buddhist ourselves."

An event led by local Karen monks that clearly defined Duwae practice within Buddhism took place in the 1970s. In 1973, four Karen abbots from local monasteries took up reconstruction of the Duwae pagoda in Dong Ying. A stone inscription in the pagoda grounds commemorating the reconstruction, states as follows: "In 1973, in Tao-pon village of Dong Ying, Paan District, on the second Thursday of the month of Kasone, 150 monks and more than 300 people gathered from Paan, Hlaingbwe, Yangon, [etc.]. The purpose of the gathering was to acknowledge the Duwae pagoda and its grounds as a place of Buddhist worship, and thereby secure and maintain Buddhist practices in the Karen region. A committee was formulated by members of the sangha." Names of four patrons, four supervisors, four treasurers, and three auditors are inscribed, all of whom are Karen monks from Paan or Kawkareik, including the former Karen abbot of Yedagone Monastery, and literary monks such as U Santana, and U Zagara. In the same year, the foundation was constructed, and the following year, the thi (umbrella) on top of the pagoda was consecrated.

Clearly at this point, the intention of local Karen monks was to locate and incorporate Duwae practice within the Buddhist fold. According to records by local monks at the time of this pagoda re-construction, after evaluating the pagoda and its related practices, they proclaimed: "Duwae pagoda is appropriate for the purpose of Buddhism” (anonymous 1973, 28). Thus, Duwae became consciously repositioned within Buddhist practices among the local Karen through the initiative of local Karen monks.

It is not clear why this conscious "Buddhicization" of Duwae by local monks took place at this point. As mentioned above, Telakhon, closely associated with Duwae, involved itself in KNU-related maneuvers against the Burmese military in 1968. It is possible that those involved in Duwae practice deemed it necessary to clearly distinguish Duwae from sects such as Telakhon, positioning it within Buddhist practice. A seventy-year old elder in Dong Ying recounted that when he was a child, villagers

\footnotetext{
${ }^{19}$ Carpenter, who visited the upper Mae Klong River on the Thai side in 1872, reported that there was a Buddhist sect in the region which worshipped "the Lord Too-way" (Carpenter 1873,11). In 1908, an abbot and nine Duwae practitioners were reported to have visited the Telakhon chief (Stern 1968, 320).
} 
never visited monasteries, but often worshipped the pagodas. It was only when he had reached adolescence (around 1945) that villagers began to frequent monasteries. For local Buddhist villagers, pagodas rather than monasteries constituted important places of worship until the last half century. The public act of approving the Duwae pagoda by local Karen monks into the Buddhist context by local monks meant reemphasizing its Buddhist origins, and legitimizing and incorporating it visibly into local Buddhist practice thereby involving locals firmly in Buddhist practices.

At present, local monks oversee the management of the pagoda, while the actual practice is carried out by secular priests and lay practitioners. In Dong Ying, there are four lay priests (kalonkoh, or Duwae saya, two male and two female) who are supported by a pagoda committee (koupaka), three secretaries, and one diviner. Visitors come daily to make vows or to ask for divination, not only from the vicinity, but also from outside the state.

\section{Wedding vows}

The most important event for Duwae practitioners is the ritual wedding vow, thissa dain (Burmese), or au kin lon tawja (Pwo Karen). After the wedding ceremony conducted by monks at home, the couples visit the pagodas to make vow. There are certain days of the lunar calendar that are especially auspicious ${ }^{20}$ and the number of couples visiting Dong Ying Pagoda in a half-day (the vows must be made before noon) of an auspicious date can number as many as two hundred. In my observation, ninety percent of the couples wear Karen clothing. The groom brings a coconut, and the bride, a betel box with rice, glutinous rice, betel with leaves, beeswax, pieces of gold foil, turmeric powder, and five cigars wrapped in white cloth. After paying ritual fees (2000 kyat, at the time equivalent to 3-4 U.S. dollars), they vow three times in Pwo Karen; the first time, the priest addresses Duwon, the second time, the priest pours the coconut juice on the ground and utters prayers to the guardian spirit of the land, and the third, again addressing Duwon.

\section{Duwae norms and the domestic realm}

Earlier, there had been much emphasis on virginity in Karen customary practice (Man Thint Naung 2006a, 5). If an unmarried maiden became pregnant, the couple would have to pay compensation to their village and thereafter be expelled (Man Ne San 2005, 3). According to a local historian, Duwon recognized the importance of existing Karen customs and norms; especially those pertaining to marriage and incorporated them into Duwae practice, emphasizing the importance of sexual morality (ibid. 60, 72, 113-124). Today, with constant labor migration of the younger generation to Thailand, marriages take place away

\footnotetext{
${ }^{20}$ In the month of Kasone, Thursdays and Saturdays before the full moon, or in Dabodwe, Tuesdays and Thursdays before the full moon are the best days, and the vow must be made before noon. According to a popular Eastern Pwo Karen song: "In the month of Kasone, when the pinma flower blooms, the sky is covered by dark clouds, and rain and thunder begin. Rice cultivation begins. Duwae followers perform worship and service in this season" (Man Thint Naung 2006a, 3).
} 
from the homeland so that the norms are no longer strictly followed. However, even in these cases, couples return to make their vows, albeit after marriage and childbirth. Otherwise, they fear disaster in the family.

As I interviewed her in front of the Buddhist altar in her house, a local woman in her forties recounted, "At Dong Ying Pagoda, we make ritual offerings and ask to be protected from all evil. If we marry without making vows, we will be driven mad. Duwae is like the guardian of the house, so we must go to report our marriage." Duwae is intimately related to the daily domestic social space.

At the fire festival (mebon-pwe) held at Dong Ying Pagoda on the full moon night of the lunar month of Dabodwe, followers bring sticks of bamboo or cane, each cut to the height of a family member, which are placed around a pillar set at the center of the pagoda grounds, forming a stack. When the full moon reaches its highest position, the monks and the koupaka members chant sutras, while women carrying coconuts and bananas circle the stack, dancing nine times in a clockwise direction, after which the bonfire is lit.

As we have seen, Duwae, for the practitioners, is first and foremost a prayer and practice to protect and bring prosperity to the domestic realm. Any mishap pertaining to health, livelihood and finance, etc., affecting the domestic realm will be an opportunity for consultation with the diviner. In the introduction to Man Thint Naung's book (2006a), a local Karen monk points out the three elements of Duwae: to follow the dhamma and moral behavior in domestic and everyday life; to show respect to other families; and to teach moral behavior to husband and wife. To that extent, it shares much in common with ancestral spirit rituals (aung xae in Pwo Karen) performed by matrilineally related kin, which are locally understood as "the festival of the women of the house," or "the festival of the spirit of the house" handed down from mother to daughter. As we have seen above, the legend of the beginnings of Duwae signifies that the practice was introduced as a substitute for spirit beliefs. One of the important spirits in Karen tradition is the spirit of the house for which the women practice this ritual aung xae. Both Man Ne San $(2005,13)$ and Man Thint Naung $(2006,101)$ mention that Duwae too is by and for women. Mothers of Duwae practitioners transmit the rules to their children. In Duwae, the mother-child line is central (Man Ne San 2005,11-14).

\section{Locations and variations}

Dong Ying Pagoda is the original location of Duwae practice, forming a cluster with smaller satellite pagodas. There are two other similar clusters centered in Kyain-Longkaing, south of Kawkareik, and Klannou, east of Zwekabin. All together, there are ten Duwae pagodas. Comparing actual ritual procedures at these pagodas, it becomes apparent that the breadth of Duwae practice is not only geographical, but also in the variety of the practices. The practices focusing on the pagodas are varied from one Duwae pagoda to another, especially in the extent to which spirit worship and elements of Buddhist practices are involved. For example, in Kyain-Longkaing, the three gems (the Buddha, the 
dhamma and the sangha) are chanted at the beginning of the vowing ritual (anon. 1973, 25; Man Thint Naung 2006, 99), just as in Buddhist ceremonies. On the other hand, the practice at Thammalone Duwae pagoda manifests clear elements of spirit ritual. The priest is a vegetarian woman whose position was inherited matrilineally. There is a shrine on her terrace, and a pagoda outside that was constructed in colonial times. Couples must first make the marital vow in front of the shrine on her terrace, and then descend to the pagoda to pray. Until recently, she had used liquor for libation in her vowing ceremonies. However, according to the priestess herself, she received a message in her dream that this was inappropriate, and changed it to lime soda. The priest of Dong Ying Pagoda recounted alternatively that the Dong Ying koupaka admonished her use of liquor and advised the priestess to use lime soda. Whichever is the case, the ritual conducted by the priestess using lime soda is identical to liquor tilting and prayer performed in the name of guardian spirits among Karen who practice spirit rituals in other locales (Hayami 2004, 144). Her interpretation of Duwae practice was definitely closer to spirit rituals than at the other pagodas.

Another location for pilgrimage of Duwae vows is a bodhi tree at Lower Yedagone Waterfall. There is no pagoda here but two intertwined bodhi trees and a shrine where a Buddha statue is installed, as if to guard the tree. The majority of couples making marital vows at Duwae pagodas visit up to four locations as if on a "vowing pilgrimage." The pilgrimage course is decided by combining the bride's and groom's respective maternal practices. According to interviews performed with forty-two couples at Dong Ying Pagoda in 2007, two-thirds of the couples vowed at two or more locations. If they visited only two, it was the Dong Ying Pagoda and the bodhi tree at this waterfall. As we have seen in Duwon's legend, the bodhi tree appears as the home of spirits. Here, led by a priestess, the bride and groom pour sacred water on the tree, and the groom circles the tree clockwise three times and then makes vows.

An older koupaka member of the Dong Ying Pagoda admitted that, strictly speaking, the ritual at Yedagone Waterfall is spirit belief. While emphasizing Duwae as a custom within Buddhist practice, elements of spirit worship are not completely eliminated, and are admitted if not encouraged. A younger koupaka member at the Dong Ying Pagoda explained: "The top part of Duwae is Buddhism, and the bottom is customs. There is no problem with that." From the point of view of practitioners and supporting Karen monks, Duwae and Buddhist practices are compatible even if sometimes needing modifications, as in the case of the Thammalone priestess.

However, monks of the Buddha Nayaka council are not persuaded. The aforementioned present abbot of Upper Yedagone Monastery, recounted: "Duwae is spirit belief, not Buddhism. The Duwae priest is a nat kadaw. But if we do not allow the local Karen to continue the practice, they will be unhappy. So we let them follow their way." Thus, from the point of view of the Buddhist authorities, Duwae practice is outside its delineation but tolerated. 
Duwae is indeed a hybrid practice, which links up with Buddhism, spirit worship as well as Karen moral and cultural practices. Its practice emphasizes the immediate relationships of kinship and marriage, securing a sense of generational continuity in the domestic realm. At the same time, the ten Duwae pagodas are spread over a wide area, sharing and maintaining Karen customs and morals. There is thus a widely dispersed community of practitioners sharing the same practices in the Paan plains and the eastern hills. By stressing this generational continuity and spatially dispersed community, and the sense that it supports a moral continuity, Duwae connects practitioners across time and space, symbolized by the geographical spread of Duwae pagodas across the landscape. Oscillating between spirit worship and Buddhist practices, emphasis on Karen customs is an expression of a connectedness that is based on shared common practice to gain power and protection.

\section{Concluding Discussion}

The foregoing description and analysis demonstrate that the dynamic processes of religion among the Pwo Karen Buddhists in the region surrounding Zwekabin cannot be considered outside the larger politico-religious context of Burma/ Myanmar. This was true in the mid-nineteenth century, and is more so now under the regime's reformist religious policies. Delineation and increasing control over Buddhist knowledge and practice by the reformist council and the Myanmafication of Buddhism cannot be ignored in understanding evolving local practices. However, it is also clear that state-defined power is not absolute. More as a result of such reinforcement in an attempt to delineate and control, there is much dynamism and intense competition over space and power in the region. Looking at the array of religious practices, some are a continuation of prior practices, while others have flourished since Myanmafication began to take effect locally in this region. On the one hand we see varied positioning vis-à-vis official Buddhism, while on the other hand we see certain commonalities across them, such as vegetarian practices, power derived from asceticism, the cultivation of the moral life drawing on Karen custom and the construction of sacred space and community.

Pagoda construction is especially revealing as it is simultaneously an act of merit-making and an occasion to visualize and demonstrate power. The Zwekabin region is scattered with pogodas, marking the power of varied sources. There is competition over sacred space in which power is demonstrated especially through pagoda construction and the demarcation of space.

Myanmafication brought state-endorsed construction of sacred space to Karen State, which until 1988 had been the locus of conflict between anti-state ethnic forces and the military. It is an attempt to redefine this region's space under the regime's hold in the name of Buddhism. Phu Taki chose to construct pagodas adjacent to the regime-endorsed abbot's pagoda grounds. Thamanya 
Sayadaw constructed his own politically "neutral" sacred space marked by vegetarianism and asceticism. U Thuzana, on the other hand, built pagodas atop the hills where the KNU was stationed, and caused the split-off of Buddhist followers from the allegedly Christian-led separatist organization. The split was conveniently used by the regime, and reinforced the image of the Buddhist Karen as "assimilated" in contrast to the Christian "rebels." Locals have continued to practice Duwae at pagodas scattered on the landscape. There is, thus, severe contestation over sacred space and power among different agents, some more politically inclined than others.

The founding legend of Duwae emphasizes that Duwon was believed to have protective powers capable of ridding people of their spirits by building pagodas. Here too, the confusion in the legends indicates that whether or not it is the power attained through Buddhist practices and through the knowledge of the Buddha's dhamma or whether it is through the power of esoteric knowledge, the consequence is not of great significance for the followers. Yet, subsequently, in 1973, the local Karen monks stood up to reconstruct the pagoda, by which they redefined and incorporated it into the local Buddhist order. This allowed the followers to continue to practice Duwae, while at the same time, from the point of view of the local Karen monks, it contributed to the grassroots fortification of Buddhism. Moreover, because the regime's authorities see it as being outside the proper delineation of Buddhism, it is beyond their control.

From the perspective of lay practitioners, the concern is not whether a practice properly meets standards set by distant central authorities, but where and how to seek the power of protection; for devotees, the criterion of legitimacy is not one of "orthodoxy." There is severe competition over sacred space and constant contestation over the definition of power from all quarters. Practices excluded by the authorities' delineation may attract grassroots devotion in the peripheries, where legitimacy is gained from other sources than the centrist delineation. The devotees are self-claimed Buddhist, yet outside the center's delineation of Buddhism, so that even as they align themselves with Buddhism, they are by no means aligned with the central power.

\section{Acknowledgments}

The research was made financially possible by a grant-in-aid for scientific research from MEXT. I am grateful to many friends who helped me in innumerable aspects of the research in Myanmar. Keiko Tosa gave me invaluable insights during our joint fieldwork in the initial stages, and Daw Mi Mi Kyaw translated the Burmese language material. I am indebted to the anonymous reviewers of this journal who gave me constructive and astute comments, and to John Holt who graciously went through the draft and gave me helpful comments. I thank you all, although all faults are of course my own. A very early version of this paper in Japanese was published in Hayashi ed. 2009, Chapter 11. 


\section{References}

Anderson, B. 1998. The Spectre of Comparisons: Nationalism, Southeast Asia and the World. London and New York: Verso.

Anonymous (circa 1973). Duwae Pagoda: The Maintenance Record of Duwae Pagoda.(in Burmese) Compiled by the Duwae maintenance committee.

Borchert, Thomas. 2008. "Worry for the Dai Nation: Sipsongpanna, Chinese Modernity, and the Problems of Buddhist Modernism." Journal of Asian Studies 67:1:107-42.

CAdy, J. 1958. A History of Modern Burma. Ithaca: Cornell University Press.

Carpenter, C. H. 1873. “A Tour among the Karens of Siam.” Baptist Missionary Magazine, 53:9-16.

Goh, Daniel P.S. 2009 "Chinese Religion and the Challenge of Modernity in Malaysia and Singapore: Syncretism, Hybridisation and Transfiguration.” Asian Journal of Social Science 37:107-137.

Gravers, M. 2001 "Cosmology, Prophets, and Rebellion among the Buddhist Karen in Burma and Thailand." Moussons 4: 3-31.

Hayami, Y. 2004. Between Hills and Plains: Power and Practice in Socio-Religious Dynamics among Karen. Kyoto: Trans-Pacific Press and Kyoto University Press.

Hayashi, Yukio, ed. 2009. Kyouiki no Jissen Shukyo: Tairikubu Tounan Ajia Chiiki to Shukyo no Toporojii. (The Practical Religion of "Boundaries"). Kyoto: Kyoto University Press.

Hayashi, Yukio. 2009. "Jobun: Tairikubu Tounan Ajia Chiiki no Shukyo to Shakai Hen-yo" (Introduction: Religious and Social Changes in Mainland Southeast Asia.) In edited by Hayashi 1-23 Kyoto: Kyoto University Press.

Номі К. Внавна. 1994. The Location of Culture. London: Routledge.

Houtman, G. 1999. Mental Culture in Burmese Crisis Politics: Aung San Suu Kyi and the National League for Democracy. Study of Languages and Cultures of Asia and Africa, Monograph Series No. 33. Tokyo: Tokyo University of Foreign Studies Institute for the Study of Languages and Cultures of Asia and Africa.

IshiI, Yoneo. 1986. Sangha, State, and Society: Thai Buddhism in History. Honolulu: University of Hawaii Press.

Jordt, InGrid. 2007. Burma's Mass Lay Meditation Movement: Buddhism and the Cultural Construction of Power. Athens, OH: Ohio University Press \& Swallow Press.

Kojıмa, T. 2009. "Gendai-Myanma-ni-okeru-bukkyo-no-seidoka-to-kyouiki-no-jissen" (Institutionalization of Buddhism and Practices in the Border Regions of Myanmar Today). In edited by Hayashi Kyoto: Kyoto University Press. 67-130.

Kwanchewan, Buadaeng. 2007. "Chumchon Talaku thi Letawngkhu: Kaan Prapsaang Manoophaap lae Kaan Pathibat." In Khaam Khawp Faa: 60 Pii Shigeharu Tanabe, edited by Kwanchewan, Buadaeng and Apinnya Phuangphuusakul, 147-174. Bangkok: Sirinthorn Anthropology Center.

Man Ne San. 2005. Thit-Sa-Taing Duwae (Duwae Vows). Yangon: Yone-Kyi-Chet Sar-pe.

Man Thint Naung. 2006a. Thit-sa Taing-Ti Thone-su-thau Duwae Zedi (The Three Duwae Pagodas for Making Vows). Yangon: Yone-Kyi-Chat Sar-Pe.

_ 2006b. Thit-sa Man-Daing Duwae Zedi, Kyain-longkaing, Thonese-thonesu, Kaukpalut, Kyone-pine, Mya-pa-taing (Duwae Pagoda for Making Vows). Yangon: Yone Kyi Chat Sar-pe.

McMahan, David. 2008. The Making of Buddhist Modernism. Oxford: Oxford University Press. 
Matthews, B. 1993. "Buddhism Under a Military Regime: the Iron Heel in Burma". Asian Survey 33:408-423.

Mendelson, M. E. 1961a. "The King of the Weaving Mountain." Royal Central Asian Journal 48:229-37.

_. 1961b. "A Messianic Buddhist Association in Upper Burma" Bulletin of School of Oriental and African Studies 24:560-80.

Mendelson, M. E. 1975. Sangha and State in Burma: A Study of Monastic Sectarianism and Leadership. Ithaca and London: Cornell University Press.

Pattana, Kitiarsa. 2005. "Beyond Syncretism: Hybridization of Popular Religion in Contemporary Thailand." Journal of Southeast Asian Studies 36(3):461-487.

Rozenberg, G. 2010. Renunciation and Power : the Quest for Sainthood in Contemporary Burma. Translated by Jessica Hackett. Monograph 59. New Haven : Yale Southeast Asia Studies.

Schoвer, J. 1988. "The Path to Buddhahood: The Spiritual Mission and Social Organization of Mysticism in Contemporary Burma." Crossroads 4(1):13-30.

— 1997. "Buddhist Just Rule and Burmese National Culture: State Patronage of the Chinese Tooth Relic in Myanmar." In History of Religions 36(3):218-243.

Scott, James C. 2009. The Art of Not Being Governed: an Anarchist History of Upland Southeast Asia. New Haven: Yale University Press.

South, A. 2003. Mon Nationalism and Civil War in Burma: the Golden Sheldrake. New York: Routledge.

Stern, T. 1968. "Ariya and the Golden Book: A Millenarian Buddhist Sect among the Karen." Journal of Asian Studies 27(2):297-328.

Stern, T. and Dodge N.D., P. "Telakhon, A Millenary Buddhist Sect among the Karen" MS. 19pp. Payap University Archives.

Tadaw, Saw Hanson. 1959. “The Karens of Burma.” Journal of the British Royal Society, 62(2).

TAMBiaH, S. J. 1996. World Conqueror and World Renouncer: a Study of Buddhism and Polity in Thailand against a Historical Background. Cambridge: Cambridge University Press.

Tin Maung Maung Than. 1993. "Sangha Reforms and Renewal of Sasana in Myanmar: Historical Trends and Contemporary Practice" In Buddhist Trends in Southeast Asia, edited by Ling T., 6-63. Singapore: ISEAS.

TosA, K. 2000. Biruma-no-Weiza-Shinko (The Weikza Beliefs in Burma) Tokyo: Keiso-shobo.

Tosa, K. 2009. "The Cult of Thamanya Sayadaw: The Social Dynamism of a Formulating Pilgrimage Site.” Asian Ethnology 68:2:239-264.

Womack, W. B. 2005. "Literate Networks and the Production of Sgaw and Pwo Karen Writing in Burma, c.1830-1930." PhD diss., School of Oriental and African Studies, University of London. 